\title{
OS JOGOS TEATRAIS DE VIOLA SPOLIN NO BRASIL
}

Ainda que se possa referir ao ano de 2020 como sendo penoso e bastante complexo no que tange ao ensino e à criação artística, nesta nossa edição fazemos constar um marco significativo - se não gratificante - para as artes da cena no Brasil. Ocorre que o trabalho a partir de jogos teatrais levado a efeito por Viola Spolin (19061994), juntamente com o filho Paul Sills (1927-2008), completou recentemente quatro décadas de sua primeira versão em língua portuguesa, publicada em nosso país.

Buscando entender um pouco os diálogos múltiplos, deslocamentos, amálgamas, críticas e dispersões pelos quais passam atualmente os jogos teatrais, três investigadores se propuseram organizar um dossiê sobre o tema. Ingrid Dormien Koudela, Robson Corrêa de Camargo e Karine Ramaldes reuniram um conjunto de textos que, na sua acepção, se compõe de três partes: 1) artigos de caráter mais conceitual; 2) textos relacionados com a experiência prática e uso dos jogos em contextos diversos; 3 ) artigos que relacionam os jogos teatrais com outras áreas do conhecimento.

Ingrid Koudela, da Universidade de São Paulo (USP), abre a primeira parte apresentando um breve histórico e levanta questões relativas aos jogos teatrais nos dias de hoje, quase sessenta anos depois da primeira edição da obra de Spolin em língua inglesa, envolvida pelas lutas antisegregacionistas nos EUA. Em seguida, temos o texto do professor Gary Schwartz, ex-aluno de Viola Spolin e fundador da Intuitive Learning Systems e da Improv Odyssey, de Seattle, Washington, ambos dedicados a explorar e expandir os ensinamento dela recebidos. O autor retoma o florescimento da improvisação nos Estados Unidos e aborda os altos e baixos do percurso de Spolin ao longo dos anos.

Em seu artigo, a professora Karine Ramaldes (Universidade Federal de Goiás UFG) estabelece uma reflexão entre o sistema de Viola Spolin e o conceito de experiência em algumas de suas abordagens, em especial a partir de escritos de William James e John Dewey. O texto de Onira Tancrede e Robson Corrêa de Camargo, ambos da UFG, relacionam aspectos metodológicos dos jogos teatrais de Spolin com as reflexões sobre o jogo simbólico e o conhecimento intuitivo conforme Jean Piaget 
(1896-1980). Por sua vez, Davi de Oliveira Pinto, da Universidade Federal de São João del-Rei (UFSJ), apresenta uma avaliação do jogo teatral a partir de questões vinculadas à leitura da cena. Finalizando esta primeira parte, a pesquisadora Rejane Arruda, da Universidade de Vila Velha (UVV), toma o trabalho cênico como figuração no sentido lacaniano do termo e trata do jogo a partir de arranjos complexos e diferentes regras visando uma relação entre caos e ordem.

A segunda parte se inicia com a reflexão de Adriana Moreira Silva (Universidade Federal do Amapá - UNIFAP) sobre uma prática artístico-pedagógica realizada com adolescentes, abordando os jogos teatrais de forma dialógica com os conceitos de viewpoints. Em seguida, a professora Alessandra Ancona de Faria (Universidade Estadual de Campinas - UNICAMP) analisa o desenvolvimento da arte na escola formal a partir da aplicação de uma obra específica de Viola Spolin. Por sua vez, Ângela Barcellos Café, da Universidade de Brasília (UNB), relata suas experiências de formação docente e reflete sobre a aplicação do jogo lúdico em experiências de estágio no ensino das artes cênicas.

Os dois artigos seguintes também se vinculam a questões de ensino e formação. Neste sentido, a contribuição de Barbara Leite Matias, da Universidade Federal de Minas Gerais (UFMG), apresenta estudos a partir de experiência em estágios de Licenciatura realizados em escola pública. Daves Otani e Raíra Rosenkjar, da Escola Superior de Artes Célia Helena (ESCH), refletem sobre procedimento aplicado na disciplina "Jogos e Pedagogia Teatral", recorrendo a Kusnet, Huizinga e Bogart.

A colaboração de Deise Pacheco, da Fundação Armando Álvares Penteado (FAAP), se dá pela abordagem de um experimento cênico bilíngue sobre a peça Entre quatro paredes, de Jean-Paul Sartre, problematizando-a com a noção de jogo teatral. Por outro lado, um breve relato do processo de inclusão do teatro junto ao sistema penitenciário de Macapá (AP) é a contribuição de Emerson de Paula Silva, da Universidade Federal do Amapá (UNIFAP), enquanto a professora Lindinalva Barboza de Souza (Faculdade Campos Elíseos - FCE) trata das técnicas teatrais de Spolin aplicadas numa encenação desenvolvida na EJA (Educação de Jovens e Adultos).

Com base no "tributo", conceito extraído da cultura carnavalesca do samba enredo, Newton Armani de Souza, professor da UFG, aponta para a prática de um possível jogo teatral desde que coerentemente acompanhada pelo exercício dos 
princípios da eutonia e do método Laban. Na sequência, a professora Onira Tancrede, também da UFG, aprofunda a relação entre o pensamento de Jean Piaget e a prática dos jogos improvisacionais de Viola Spolin numa experiência escolar em que constata o desenvolvimento do pensamento intuitivo. Por fim, oficinas de contação de histórias ministradas a professores da rede pública em Goiânia (GO) constituem a base da reflexão de Valquíria Duarte (Universidade Federal de Goiás - UFG), que trata de possíveis relações de tal ato com os jogos teatrais.

A parte final desta primeira seção, reunindo textos que relacionam os jogos teatrais com outras áreas do conhecimento, conta com o artigo de Lúcia Lombardi e Fernanda Antunes de Souza, da Universidade Federal de São Carlos (UFScar). O trabalho revela a desestabilização de valores cristalizados no modelo de hegemônico de escolarização e a importância de se valorizar a experiência como meio de aprendizado a partir dos jogos. Concluindo a seção Mestres do Século, o professor Mateus Schimith (Universidade Federal da Bahia - UFBA) toma por base a prática improvisacional numa correlação do jogo no teatro com o jogo de capoeira.

A seção Instrumentos e Métodos compõe-se de três artigos e, coincidentemente, a primeira colaboração é de uma professora da UFG, tendo também como tema a capoeira. Renata de Lima trata da dilatação da presença nos preceitos da Antropologia Teatral proposta por Eugenio Barba, considerando especialmente elementos da cultura negra. O artigo de Márcia Berselli e Juliana Gedoz Tieppo, da Universidade Federal de Santa Maria (UFSM), reflete sobre a função da encenação em modo colaborativo de criação cênica, apresentando procedimentos empregados e discutindo sobre demandas do encenador contemporâneo. O Teatro Experimental do Negro é o tema proposto por Denise Rocha, da Universidade Federal do Ceará (UFC), trazendo à tona o propósito de Abdias do Nascimento em acabar com os estereótipos na cena cultural nacional, visando a valorização de artistas de origem africana. Sob a perspectiva do racismo, do colonialismo e da cor de pele, o artigo se mostra em compasso com a atualidade, abordando a questão pela ótica da tragédia grega.

O Editor

João Pessoa, UFPB

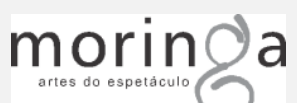

